\title{
Türkiye'de Yetiştirilen Bazı Ekmeklik Buğday Çeşitlerinin Yarı Kurak İklim Koşullarında (T. Aestivum L.) Kalite Özellikleri İle Verim ve Verim Unsurlarının İncelenmesi
}

\author{
Arzu Mutlu ${ }^{1}$, Timuçin Taş ${ }^{2 *}$ \\ ${ }^{1}$ Harran Üniversitesi, Ziraat Fakültesi, Akçakale Meslek Yüksekokulu, Şanlıurfa, Türkiye (ORCID: 0000-0001-8992-8371) \\ ${ }^{2}$ GAP Tarımsal Araştırma Enstitüsü Müdürlüğü, Şanlıurfa, Türkiye (ORCID: 0000-0002-2144-9064)
}

(İlk Geliş Tarihi 18 Nisan 2020 ve Kabul Tarihi 26 Mayıs 2020)

(DOI: 10.31590/ejosat.738796)

\begin{abstract}
ATIF/REFERENCE: Mutlu, A. \& Taş, T. (2020). Türkiye'de Yetiştirilen Bazı Ekmeklik Buğday Çeşitlerinin Yarı Kurak İklim Koşullarında (T. Aestivum L.) Kalite Özellikleri İle Verim ve Verim Unsurlarının İncelenmesi. Avrupa Bilim ve Teknoloji Dergisi, (19), 344-353.

$\ddot{\mathbf{O} z}$

Bu araştırma, 2018-2019 yetiştirme sezonunda Şanlıurfa ilinin Akçakale ilçesi çiftçi koşullarında 25 ekmeklik buğday çeşidi ile tesadüf blokları deneme desenine göre 3 tekerrürlü olarak yürütülmüştür. Yarı kurak iklim koşullarında ekmeklik buğday çeşitlerinin tane verimi ile bazı verim unsurları ve kalite özelliklerinin belirlenmesi amacıyla yürütülmüștür. Denemede tane verimi, verim unsurları (bitki boyu, hektolitre ve bindane) ve bazı kalite özellikleri (protein oranı, yaş gluten, kuru gluten oranı ve sedimantasyon miktarı) incelenmiş̧tir. Araştırma sonuçlarına göre; tane veriminin; $293.0-666.0 \mathrm{~kg} / \mathrm{da}$, bitki boyunun; 80.14-110.00 cm, hektolitre ağıllığının; 69.70-82.18 kg/hL, bindane ağıllığının; 23.73-45.08 gr, protein oranının; \% 12.97-16.00, yaş gluten oranının; \% 28.3343.47, kuru gluten oranının; \% 9.93-16.23, sedimentasyon miktarının; 24.00-48.33 ml arasında değiştiği belirlenmiştir. Denemenin birinci yılına göre; ikinci yılında yaklaşık $1000 \mathrm{~mm}$ yağan yağış ve buna bağlı düşük sıcaklıklardan dolayı tane verimi, verim komponentleri ve kalite değerlerinin azaldığı görülmüsştür. Yapılan biplot analizinde, hem tane verimi ile verim komponentleri'nin hem de kalite özelliklerinin birbirleri ile yüksek pozitif ilişkilere sahip olduğu belirlenmiştir. Her özellik bakımından yüksek stabiliteye sahip çeşitler tespit edilmiştir. Tane verimi bakımından Pamukova-97, Kaşifbey, Adana-99, PANDA`S ve Gökkan çeşitlerin stabil ve kabul edilir sınırlarda kalite özelliklerine sahip olduğu saptanmıştır.
\end{abstract}

\section{Investigation of Quality Traits with Yield and Yield Elements in Some Bread Wheat Varieties (T. Aestivum L.) Grown in Turkey under Semi- Arid Climatic Conditions}

\begin{abstract}
This research was coducted with 25 bread wheat varieties at farmer conditions in Akçakale district of Şanlıurfa province in 2018 and 2019 growing season according to a randomized complete block design with there replications. It was carried out to determine of quality traits with yield and yield elements in some bread wheat varieties (T. Aestivum L.) under semi-arid climatic conditions. Grain yield, yield elements (plant height, hectolitre and 1000 kernels weight) and some quality traits (protein ratio, wet gluten and dry gluten ratio and sedimentation amount) were analyzed in trial. According to the research results, it was determined that grain yield, plant height, hectolitre weight, 1000 grain weight, protein ratio, wet gluten ratio, dry gluten ratio and sedimentation amount ranged from $293.0-666.0 \mathrm{~kg} / \mathrm{da}^{-1}, 80.14-110.00 \mathrm{~cm}, 69.70-82.18 \mathrm{~kg} / \mathrm{hL}^{-1}, 23.73-45.08 \mathrm{~g}, 12.97-16.00 \%$, 28.33-43.47 \%, 9.93-16.23 \% and 24.00$48.33 \mathrm{ml}$ respectively. According to the first year of the trial; it was observed that grain yield, yield components and quality values decreased due to the precipitation about $1000 \mathrm{~mm}$ and low temperatures in the second year. In the biplot analysis, it was determined
\end{abstract}

*Sorumlu Yazar: GAP Tarımsal Araştırma Enstitüsü Müdürlügü̈, Şanlıurfa, Türkiye, ORCID: 0000-0002-2144-9064, ttas_4@hotmail.com 
that both grain yield with yield components and quality characteristics have high positive relationships with each other. Genotypes which had high stability in terms of each feature was identified. In terms of grain yield, varieties which are Pamukova-97, Kaşifbey, Adana-99, PANDA'S and Gökkan was determined to have both stable and quality features within acceptable quality limits.

Keywords: Bread Weat, Grain Yield, Quality Traits, Biplot Analysis

\section{Giriş}

Buğday ülkemizde ve dünyada temel besin maddesi ve stratejik ürün olarak ilk sırayı almakta ve bu önemi gelecek yıllarda da sürdüreceği görülmektedir. 2018-19 üretim sezonunda Dünyada toplam buğday üretimi 733 milyon ton olmuştur. 2019-20 üretim sezonunda ise 763 milyon ton olması tahmin edilmektedir (Anonim, 2020a). Türkiye'de 2019 yılı buğday ekilişi 68,5 milyon dekar, toplam üretim 19 milyon tondur. 57,5 milyon dekar alanda 15,85 milyon ton ekmeklik buğday, 11 milyon dekar alanda da 3,15 milyon ton makarnalık buğday üretilmiştir (Anonim, 2020b). Türkiye'nin 2018/2019 pazarlama yılı toplam buğday tüketimi 18,8 milyon ton ve kendine yeterliliği \%100,5’tir. Araştırmanın yürütüldüğü Şanlıurfa ili hem makarnalık hem de ekmeklik buğday yabani formlarını doğal florasında barındırması yönüyle kaliteli ekmeklik ve makarnalık buğday üretiminin yapıldığı bir ildir. Türkiye buğday üretiminin yaklaşık \% $5 \mathrm{i}$ bu ilimizden elde edilmektedir (Anonim, 2020b).

Ekmeklik buğdayın verim ve kalite özelliklerine birçok çevresel faktörün etkisi bulunmaktadır. Farklı gübreleme dozları, yıllık yağış miktarı ve dağılımı, yetiştirme periyodu, özellikle tane doldurma dönemindeki sıcaklık ve nisbi nem oranları gibi çevresel faktörlerin en önemlilerinden olduğu rapor edilmiştir (Peterson ve ark., 1998; Smith ve Gooding, 1999). Tarımı yapılan bölgelerdeki toprak ve iklim özelliklerinin ekmeklik buğday çeşitlerinin kalite özelliklerine önemli etkisi olduğu bildirilmiştir (Atll, 1999). Tane verimi ile pozitif bir korelasyon içerisinde olan bindane ve hektolitre gibi agronomik özellikler; çeşit, iklim (sıcaklık, yağış ve nisbi nem), toprak özellikleri ve tane dolumu sırasındaki sıcaklık ve yağış rejimi gibi faktörler tarafından etkilenmektedir. Ekmeklik buğdaydaki kalite özellikleri (gluten ve sedimentasyon) önemli ölçüde protein oranları ile paralellik gösterir. Protein, gluten ve sedimentasyon miktarlarının farklı çevre ve genotiplerde farklı değerler aldığı, gluten oranının en önemli kalite özelliklerinden biri olan sedimentasyon miktarının; çeşit, farklı yetiştirme çevreleri ve ekmeklik buğdayın en önemli zararlılarından olan süne ve kımıla bağlı olarak değişebileceği rapor edilmiştir (Bonfil ve ark., 2004). Depo edilen proteinlerin büyük bir bölümünü oluşturan gliadin proteini, glutenin büyük bir bölümünü teşkil etmektedir. Bu proteinin maya tarafından oluşturulan gazı tutarak, kaliteli ekmeğin oluşmasını sağladığı ifade edilmiştir (Elgün ve ark., 2001). Bu sebeplerden dolayı, üretime kazandırılmış ve kazandırılacak olan ekmeklik buğday çeşitlerinin tane verimlerinin yanında kalite yönünden de değerlendirilmesi ve irdelenmesi gerektiği belirtilmiştir (Basset ve ark., 1989).

Bu çalışma, Şanlıurfa iline bağlı Akçakale ilçesi çiftçi koşullarında, ülkenin farklı Ar-Ge kuruluşları tarafından geliştirilen ve hala üretim alanlarında tercih edilen, yazlık ve kışlık tabiatlı ekmeklik buğday çeşitlerinin verim performanslarının yanında kalite performanslarını belirlemek ve ilişkilendirmek amacıyla yürütülmüştür.

\section{Materyal ve Metot}

2018 ve 2019 yillarında Akçakale ilçesi çiftçi tarlasından alınan toprak numunelerinin analizleri neticesinde, her iki yılda organik madde oranı dışında kalan özelliklerin bitki gelişimi için kabul edilir seviyelerde olduğu belirlenmiştir (Tablo 1). Araştırmanın yürütüldüğü yer olan Şanlıurfa ili, Türkiye'nin en sıcak iklim kuşağında yer alan illerinden birisidir. 2017/2018 yetiştirme sezonunda sıcaklıkların 2018/2019 yetiştirme sezonuna ve uzun yıllara göre daha yüksek seyrettiği belirlenmiştir. Araş̧ırmanın ikinci yılında toplam yağış miktarının 1000 mm'ye yaklaşarak, araştırmanın ilk yılı yağış miktarının yaklaşık üç katına ulaştığı tespit edilmiştir. Denemenin ikinci yılında yoğun yağışlardan dolayı deneme parsellerinde günler süren göllenmeler meydana gelmiştir. Araştırmanın ikinci yılı yoğun yağışların olduğu dönemlerde bitkilerin gelişiminin yavaşladığı yer yer bitkilerin yapraklarında sararmalar olduğu gözlemlenmiştir. Her iki deneme yılında da düzenli bir yağış rejimi olmadığı için özellikle bitkinin tane doldurma döneminde sulamalar yapılmışıı (Tablo 2).

Tablo 1. 2018 ve 2019 Yllları Deneme Alanında ki Toprakları Özellikleri

\begin{tabular}{lllll}
\hline YILLAR & \multicolumn{2}{c}{$\mathbf{2 0 1 8}$} & & $\mathbf{2 0 1 9}$ \\
\hline Toprak Derinliği (cm). & $\mathbf{0 - 3 0}$ & $\mathbf{3 0 - 6 0}$ & $\mathbf{0 - 3 0}$ & $\mathbf{3 0 - 6 0}$ \\
\hline Ec $(\mathrm{dS} \mathrm{m})$ & 0.67 & 0.74 & 0.71 & 0.69 \\
pH & 7.60 & 7.70 & 7.40 & 7.50 \\
Kireç oranı (\%) & 31.2 & 32.0 & 21.0 & 22.78 \\
Toplam P (kg/da) & 4.02 & 4.55 & 6.43 & 6.10 \\
Toplam K (kg/da) & 244.88 & 233.89 & 260.0 & 270.20 \\
Organik madde oranı (\%) & 1.11 & 0.89 & 0.73 & 0.91 \\
Cu (mg kg-1) & 1.24 & 1.31 & 1.34 & 1.38 \\
Mn $\left(\mathrm{mg} \mathrm{kg}^{-1}\right)$ & 5.55 & 5.44 & 4.66 & 4.35 \\
Fe $\left(\mathrm{mg} \mathrm{kg}^{-1}\right)$ & 6.10 & 6.31 & 5.56 & 5.50 \\
$\mathrm{Zn}\left(\mathrm{mg} \mathrm{kg}^{-1}\right)$ & 1.03 & 1.38 & 1.40 & 1.25 \\
\hline
\end{tabular}




\begin{tabular}{|c|c|c|c|c|c|c|c|c|c|c|c|c|}
\hline \multirow[b]{2}{*}{ Aylar } & \multicolumn{3}{|c|}{ Ort. Sicaklık $\left({ }^{\circ} \mathbf{C}\right)$} & \multicolumn{3}{|c|}{$\begin{array}{c}\text { Ort. En Yüksek Sıcaklık } \\
\left({ }^{\circ} \mathbf{C}\right)\end{array}$} & \multicolumn{3}{|c|}{$\begin{array}{c}\text { Ort. En Düşük Sicaklık } \\
\left({ }^{\circ} \mathbf{C}\right)\end{array}$} & \multicolumn{3}{|c|}{ Toplam Yağıș $\left(\mathrm{kg} / \mathrm{m}^{2}\right)$} \\
\hline & $\begin{array}{c}2017- \\
18\end{array}$ & $\begin{array}{c}2018- \\
19\end{array}$ & $\begin{array}{l}\text { Uzun } \\
\text { yillar }\end{array}$ & $\begin{array}{c}2017- \\
18 \\
\end{array}$ & $\begin{array}{c}2018- \\
19\end{array}$ & $\begin{array}{l}\text { Uzun } \\
\text { yillar }\end{array}$ & $2017-18$ & $\begin{array}{c}2018- \\
19\end{array}$ & $\begin{array}{l}\text { Uzun } \\
\text { yillar }\end{array}$ & $\begin{array}{c}2017 \\
-18 \\
\end{array}$ & $\begin{array}{c}2018- \\
19\end{array}$ & $\begin{array}{l}\text { Uzun } \\
\text { yillar }\end{array}$ \\
\hline Ekim & 20.5 & 21.6 & 20.2 & 27.3 & 27.7 & 27.0 & 15.1 & 16.8 & 14.5 & 17.1 & 39.4 & 24.6 \\
\hline Kasım & 13.4 & 13.0 & 12.8 & 19.0 & 17.6 & 18.7 & 9.2 & 9.5 & 8.4 & 17.4 & 106.6 & 44.9 \\
\hline Aralık & 10.3 & 8.6 & 7.5 & 15.9 & 12.0 & 12.0 & 6.3 & 6.1 & 3.9 & 9.5 & 259.2 & 80.1 \\
\hline Ocak & 8.1 & 6.1 & 5.5 & 12.4 & 10.3 & 9.9 & 4.9 & 3.2 & 2 & 118.8 & 113.8 & 87.7 \\
\hline Şubat & 10.4 & 8.3 & 7.0 & 15.2 & 13.2 & 11.9 & 6.7 & 4.7 & 2.9 & 87.4 & 83.8 & 69.2 \\
\hline Mart & 15.5 & 10.7 & 10.8 & 21.6 & 16.0 & 16.4 & 9.9 & 6.6 & 5.8 & 13.3 & 156.7 & 62.1 \\
\hline Nisan & 19.9 & 14.4 & 16.1 & 27.0 & 20.4 & 22.3 & 13.6 & 9.8 & 10.3 & 35.8 & 97.4 & 49.4 \\
\hline Mayıs & 23.0 & 25.2 & 22.1 & 29.8 & 32.6 & 28.6 & 17.0 & 17.9 & 15.2 & 64.5 & 7.3 & 26.1 \\
\hline Haziran & 28.6 & 30.7 & 28.1 & 36.2 & 38.3 & 34.6 & 21.5 & 22.9 & 20.5 & 10.1 & 8.9 & 3.5 \\
\hline Ortalama & 16.6 & 15.4 & 14.5 & 22.7 & 20.9 & 20.1 & 11.5 & 10.8 & 9.2 & 373.9 & 873.1 & 447.6 \\
\hline
\end{tabular}

Araştırma, 2017/2018 - 2018/2019 yetiştirme sezonlarında Şanlıurfa'nın Akçakale ilçesi çiftçi şartlarında tesadüf blokları deneme desenine göre üç tekerrürlü olarak yürütülmüştür. Araştırmada bitki materyali olarak, ülkenin farklı Ar-Ge kuruluşlarında geliştirilmiş çoğu yazlık tabiatlı olmak üzere kışlık tabiatlı çeşitlerin de olduğu 25 ekmeklik buğday çeşidi kullanılmıştır. Çeşitlerin tohumluk miktarları TIGGM kurumundan temin edilmiştir (Tablo 3).

Tablo 3. 2018-2019 Yetiştirme Sezonunda Denenen Ekmeklik Buğday Çeşitleri

\begin{tabular}{|c|c|c|}
\hline Kod & Çeşitler & Tescil Edildiği Kuruluş \\
\hline 1 & Tosunbey & Tarla Bitkileri Merkez Araştırma Enstitüsü Müdürlüğü \\
\hline 2 & Bayraktar 2000 & Tarla Bitkileri Merkez Araştırma Enstitüsü Müdürlüğü \\
\hline 3 & Gönen-98 & Ege Tarımsal Araştırma Enstitüsü Müdürlüğü \\
\hline 4 & Dicle 21 & GAP Uluslararası Tarımsal Araştırma ve Eğitim Merkezi \\
\hline 5 & Karacadağ-98 & GAP Uluslararası Tarımsal Araştırma ve Eğitim Merkezi \\
\hline 6 & Gerek 79 & Geçit Kuşağı Tarımsal Araştırma Enstitüsü Müdürlüğü \\
\hline 7 & Pehlivan & Trakya Tarımsal Araştırma Enstitüsü Müdürlüğü \\
\hline 8 & Sönmez 2001 & Tarla Bitkileri Merkez Araştırma Enstitüsü Müdürlüğü \\
\hline 9 & İkizce-96 & Tarla Bitkileri Merkez Araştırma Enstitüsü Müdürlüğü \\
\hline 10 & Altay-2000 & Geçit Kuşağı Tarımsal Araştırma Enstitüsü Müdürlüğü \\
\hline 11 & Nurkent & GAP Uluslararası Tarımsal Araştırma ve Eğitim Merkezi \\
\hline 12 & Pamukova-97 & Mısır Araştırma Enstitüsü Müdürlüğü \\
\hline 13 & Bezostaja 1 & Mısır Araştırma Enstitüsü Müdürlüğü \\
\hline 14 & Golia & Trakya Tarımsal Araştırma Enstitüsü Müdürlüğü \\
\hline 15 & Kaşifbey & Ege Tarımsal Araştırma Enstitüsü Müdürlüğ̈̈ \\
\hline 16 & Adana-99 & Doğu Akdeniz Tarımsal Araştırma Enstitüsü Müdürlüğü \\
\hline 17 & PANDA`S & Doğu Akdeniz Tarımsal Araştırma Enstitüsü Müdürlüğü \\
\hline 18 & Cemre & GAP Uluslararası Tarımsal Araştırma ve Eğitim Merkezi \\
\hline 19 & Aldane & Trakya Tarımsal Araştırma Enstitüsü Müdürlüğü \\
\hline 20 & Gökkan & Doğu Akdeniz Tarımsal Araştırma Enstitüsü Müdürlüğü \\
\hline 21 & Yüreğir-89 & Doğu Akdeniz Tarımsal Araştırma Enstitüsü Müdürlüğü \\
\hline 22 & Kınac1-97 & Trakya Tarımsal Araştırma Enstitüsü Müdürlüğü \\
\hline 23 & Ceyhan 99 & Doğu Akdeniz Tarımsal Araştırma Enstitüsü Müdürlüğü \\
\hline 24 & Tekin & GAP Uluslararası Tarımsal Araştırma ve Eğitim Merkezi \\
\hline 25 & Dariel & İsrail Orjinli \\
\hline
\end{tabular}

Deneme alanında ön bitki olan mısır üretiminden sonra derin sürüm yapılmış daha sonra sonbaharda ilk yağmurlardan sonra kültivatör ve tapan çekilerek ekime hazır hale getirilmiştir. Dekara $25 \mathrm{~kg}$ tohum hesabı ile parsellerin alanı, mibzerle ekimde 1.2 × $6=$ $7.2 \mathrm{~m}^{2}$ olacak şekilde ayarlanmıştır. Araştırmanın birinci ve ikinci yıl ekimleri sırasıyla; 09/11/2017 ve 11/11/2018 tarihlerinde yapılmıştır. Ekimle birlikte parsellere, $6 \mathrm{~kg} / \mathrm{da} \mathrm{P}_{2} \mathrm{O}_{5}$ ve $\mathrm{N}$, üst gübrelemede dekara $8 \mathrm{~kg} / \mathrm{da}$ saf olacak şekilde $\mathrm{N}$ verilmiştir. Dar ve geniş yapraklı yabancı otlara karşı herbisit ilaçlaması yapılmıştır. Denemenin ikinci yılında yoğun yağışlara rağmen, tane doldurma e-ISSN: 2148-2683 
döneminde yetersiz yağıştan dolayı bir sulama, denemenin ilk yılında tane doldurma döneminde ise iki defa sulama yapılmıştır. Her sulama yaklaşık $100 \mathrm{~mm} / \mathrm{da}$ olacak şekilde ayarlanmıştır. Denemenin her iki tarafindan $0.5 \mathrm{~m}$ alınmış ve hasat, deneme biçerdöveri ile $1.2 \times 5=6 \mathrm{~m}^{2}$ üzerinden tam olum döneminde yapılmıştır.

Araştırmada genotiplerin tane verimi, verim unsurları (bitki boyu, hektolitre ve bindane ağırlı̆ı̆) ve bazı kalite özellikleri (protein oranı, yaş gluten, kuru gluten, sedimantasyon miktarı,) incelenmiştir. Hasattan sonra parselden elde edilen tüm daneler üzerinden dekara verim miktarı hesaplanmıştır. Her parselden alınan buğday örneklerinden, ICC standart metoduna göre (AACC Metot 46-30) Celdhl NIT (near infrared transmitace) spektroskopi tekniği kullanılarak protein oranları belirlenmiştir (Anonymous, 1990). AACC 55-10 metoduna göre, bin tane ağırlı̆ı işlemi 4 tekrarlamalı olarak yabancı maddesi temizlenmiş buğdaydan 100 adet tane sayılmış ve ağırlı̆̆ı tartılarak ortalamaları alınmış çıkan sonuç 10 ile çarpılarak bin tane ağırlığı bulunmuştur (Anonymous, 1990). Loyka marka hektolitre tayin cihazı kullanılarak 1 litre hacimli buğdayın ağırlığı tartılıp, bulunan değer 100 ile çarpılmış ve buğday örneklerinin hektolitre ağırlığı $\mathrm{kg}$ cinsinden hesaplanmıştır (Ünal, 2002). Yaş ve kuru gluten değerleri AACC Metod 56-60.01 metoduna göre yapılmıştır. Analiz yapılacak örnekler Chopin marka (Moulin Cd Type) değirmen yardımı ile öğütülüp un haline getirilmiştir. Elde edilen 10'ar g'lık un numuneleri gluten yıkama cihazının elekli sağ ve sol bölümlerine yerleştirilerek numunelerin üzerine \%2'lik $\mathrm{NaCI}$ çözeltisinden $5.2 \mathrm{ml}$ ilave edilip yoğrularak hamur haline getirildikten sonra \%2'lik $\mathrm{NaCI}$ çözeltisinde yıkama işlemi uygulanmıştır. Böylece nişasta, suda çözünen (albumin) ve tuzlu suda çözünen (globulin ve proteoz) proteinleri ile diğer maddeler ortamdan uzaklaştırılmış ve geriye çözünmeyen elastik yapıdaki materyal olan yaş gluten ağırlığı eşitlik 1'deki gibi bulunmuştur [1]. Elde edilen yaş gluten, eleklere konularak $6.000 \mathrm{~d} / \mathrm{dk}$ hızla $1 \mathrm{dk}$ süreyle santrifüj edilmiştir. Santrifüj işlemi sonunda elekten geçip santrifüj duvarına yapışan kısım çürük, elek üstünde kalan kısım da sağlam kısım olarak adlandırılmıştır. Bu kısımlar ayrı ayrı tartılarak elde edilen değerler formülde yerine yazılmış, yaş gluten değeri eşitlik 2'deki gibi \% olarak hesaplanmıştır [2]. Yaş glutene glutork cihazında 5 dakika süreyle sıcaklık uygulaması yapılarak içinde bulunan suyun uçması sağlanmıştır. Süre sonunda kurumuş olan gluten tartılarak bulunan değer formülde yerine yazılmış ve kuru gluten oranı eşitlik 3'deki gibi \% olarak bulunmuştur [3] (Pfluger ve ark., 2001). Sedimentasyon değeri AACC Metod 56-60.01 metoduna göre hesaplanmıştır. Un ve laktik asit çözeltisi karıştırılarak hazırlanmış süspansiyondaki un partiküllerinin gluten miktar ve kalitesine göre şişmesi ve şişen partiküllerin belirli zaman içinde çöken miktarının ölçülmesiyle bulunmuştur. $3.2 \mathrm{~g}$ un numuneleri tartılıp sedimentasyon tüpünün içine $50 \mathrm{ml}$ brom fenol çözeltisi eklenip kapağı kapatılmıştır. Kapatılan tüp $12 \mathrm{kez}$ çalkalanmış ve sedimentasyon cihazına yerleştirilmiştir. Cihazda $5 \mathrm{dk}$ bekletildikten sonra üzerine $25 \mathrm{ml}$ laktik asit çözeltisi eklenerek $5 \mathrm{dk}$ süreyle çalkalanmıştır. Daha sonra tüpler cihazdan alınarak uygun bir yerde $5 \mathrm{dk}$ süreyle bekletilmiştir. Bekleme süresi sonunda tüpün alt kısmında çöken un seviyesi ml olarak hesaplanmıştır (Pena ve ark., 1990).

Yaş Gluten ağırlığı $(\mathrm{g})=$ Çürük Gluten $(\mathrm{g})+$ Sağlam Gluten $(\mathrm{g})$.

$\%$ Yaş Gluten $=[$ Yaş gluten ağılığı $(\mathrm{g}) /$ Un örneğinin ağırlığ $(\mathrm{g})] * 100$.

$\%$ Kuru Gluten $=[$ Kuru gluten ağırlı̆̆ $(\mathrm{g}) /$ Un örneğinin ağırlığı $(\mathrm{g})] * 100$.

Araştırmada ele alınan özelliklere ilişkin veriler tesadüf blokları deneme desenine göre JMP 13.0 istatistik programı kullanılarak varyans ve Biplot analizine tabi tutulmuştur. Çeşitlere ait ortalamaların karşılaştırılmasında LSD testi kullanılmıştır.

\section{Araştırma Sonuçları ve Tartışma}

İki y1lın birleştirilmiş varyans analizinde BB, YG ve KG parametrelerinde yıllar arasında istatistiksel olarak önemli farklar elde edilmiştir $(\mathrm{P} \leq 0.05)$. YG ve KG parametrelerinin yıl $\mathrm{x}$ çeşit interaksiyonunda istatistiksek olarak bir fark bulunamamıştır. Bunlar dışında kalan özellikler için yıl, çeşit ve yıl x çeşit interaksiyonlarına ilişkin kareler ortalamalarında istatistiki olarak önemli farklar elde edilmiştir ( $\mathrm{P} \leq 0.01)$ (Tablo 4).

Tablo 4. 2018-2019 yıllarında Denenen 25 Ekmeklik Buğday Çeşidinin Verim ve Bazı Kalite Özelliklerine İlişkin Birleştirilmiş Varyans Analizi Sonuçları

\begin{tabular}{llllllllll}
\hline Kaynak & SD & BB $(\mathbf{c m})$ & HA $(\mathbf{k g} / \mathbf{h L})$ & BA $(\mathbf{g r})$ & YG $(\%)$ & KG $(\%)$ & S (ml) & PO (\%) & TV (kg/da) \\
\hline Y1l & 1 & $1017.695^{*}$ & $245.120^{* *}$ & $3619.948^{* *}$ & $838.322^{*}$ & $72.593^{*}$ & $1795.740^{* *}$ & $9.882^{* *}$ & $382958.786^{* *}$ \\
Tek (Y1l) & 4 & 75.272 & 4.223 & 22.933 & 105.711 & 8.901 & 28.460 & 0.689 & 2544.258 \\
Çeşit & 24 & $206.370^{* *}$ & $16.240^{* *}$ & $34.727^{* *}$ & $39.884^{* *}$ & $5.929^{* *}$ & $75.625^{* *}$ & $1.426^{* *}$ & $19564.010^{* *}$ \\
Y11 Çeşit & 24 & $73.249^{* *}$ & $9.871^{* *}$ & $15.373^{* *}$ & 7.375 & 2.789 & $28.032^{* *}$ & $0.852^{* *}$ & $21615.857^{* *}$ \\
Hata & 96 & 24.509 & 4.444 & 3.460 & 10.331 & 1.861 & 13.481 & 0.230 & 3868.118 \\
CV & & 5.12 & 2.76 & 5.29 & 9.10 & 10.77 & 10.96 & 3.33 & 12.97 \\
Ortalama & & 96.57 & 76.25 & 35.11 & 35.29 & 12.66 & 33.50 & 14.39 & 479.26
\end{tabular}

+ BB: Bitki Boyu (cm), HA: Hektolitre Ağırlı̆̆ı (kg/hL), BA: Bindane Ağırlı̆̆ (gr), YG: Yaş Gluten (\%), KG: Kuru Gluten (\%), S: Sedimentasyon (ml), PO: Protein Oranı (\%), TV: Tane Verimi (kg/da), ***: Sirasıyla $\mathrm{P} \leq 0.05$ ve $\mathrm{P} \leq 0.01$ olasılık düzeylerinde önemli,

\subsection{Bitki Boyu (BB, cm)}

Bütün çeşitlerin iki yıldaki ortalama bitki boyu değerleri 82.57 (Karacadağ-98) ile 109.35 (İkizce-96) cm arasında değiştiği belirlenmiştir. Denemede, iki yılın bitki boyu ortalaması $96.57 \mathrm{~cm}$ olup, Tosunbey, Gönen-98, Gerek 79, Pehlivan, Sönmez 2001, İkizce-96, Altay-2000, Nurkent, Bezostaja 1, Golia, Aldane ve Gökkan çeşitlerinin bu ortalamanın üstünde değerler aldığı tespit edilmiş̧tir (Tablo 5). Denemenin ikinci yılındaki aşırı yağışlar, birinci yıla oranla bitkileri olumsuz etkilemiş ve bitki boylarının kısa e-ISSN: $2148-2683$ 
kalmasına sebep olduğu tespit edilmiştir. Deneme alanındaki yoğun yağışlardan dolayı kök bölgesinde göllenmelerin olduğu, bunun neticesinde sağlıklı bir kök gelişiminin sağlanamadığı ve bitkinin üst aksamlarının (yaprak ve sap) yeterli düzeylere ulaşamadığı gözlemlenmiştir. Araştırmadan elde edilen sonuçlar; Bayhan ve ark., (2019)'nın sonuçlarının üstünde değerler aldığı saptanmıştır.

\subsection{Hektolitre Ağgrlığı (HA, kg/hL)}

Araştırmanın her iki yılında bütün çeşitlerin ortalama hektolitre değerleri 73.27 (Karacadağ-98) ile 81.03 (Bezostaja 1) kg/hL arasında değiştiği belirlenmiştir. Denemedeki iki yılın hektolitre ortalamasının; $76.25 \mathrm{~kg} / \mathrm{hL}$ olup, Tosunbey, Gönen-98, Gerek 79, Pehlivan, Nurkent, Pamukova-97, Bezostaja 1, Aldane, Gökkan, Yüreğir-89 ve Tekin ekmeklik buğday çeşitlerinin bu ortalamanın üstünde değerler aldığı tespit edilmiştir (Tablo 5). Bindane ağırlıklarında olduğu gibi, araştırmanın ikinci yılındaki aşırı yağışlar göllenmelere sebep olmuş, göllenmeler neticesinde bitkinin kök bölgesinin gelişmediği ve havasız kaldığı, havasız kalan bitkilerin üst aksam gelişiminin yavaşladığı ve yapraklarda sararmalar olduğu görülmüştür. Bu olumsuzluklar sebebiyle fotosentez miktarının düștüğü ve tanelerin cılız kaldığı, cılız kalan çeşitlerin hektolitre ağırlıklarının düştüğü düşünülmektedir. Hektolitre ağıllığı, buğdayın kalitesi üzerine etkili olan ve en çok kullanılan fiziki kalite kriterlerinden birisidir. Hektolitre ağırlığı üzerine çeşit kapasitesinin ve iklim koşullarının etki ettiği ve onun miktarını değiştirdiği belirlenmiştir. Çeşit ıslahında bindane ağırlığında olduğu gibi, hektolitre ağırlığı en önemli kalite ve verim kriterlerinden birisidir. Araştırmadan elde edilen sonuçlar; Aydoğan ve Soylu (2017)'nun sonuçları ile uyumlu, Olgun ve ark., (2019)'nın sonuçlarının altında değerler aldığı tespit edilmiştir.

\subsection{Bindane Ăğırlı̆̆ı (BA, gr)}

Ekmeklik buğday çeşitlerinin 2018 ve 2019 yıllarının ortalama bindane ağırlıkları, 30.73 (Gerek 79) ile 40.72 (Yüreğir-89) gr arasında değiştiği tespit edilmiş̧tir. İki yıllık araştırmanın bindane ağırlıkları ortalaması 35.11 gr olup, Dicle 21, Altay-2000, Nurkent, Pamukova-97, Kaşifbey, Adana-99, PANDA`S, Cemre, Aldane, Gökkan, Yüreğir-89, Kınacı-97 ve Tekin çeşitlerinin bu ortalamanın üstünde değerler aldığı belirlenmiştir (Tablo 5). Hektolitre ağırlıklarında olduğu gibi, denemenin ikinci yılındaki yoğun ve düzensiz yağışlar bindane ağırlıklarını da olumsuz etkilemiştir. Yaşanan yoğun yağış ve göllenmeler kök gelişiminin ve fotosentez faaliyetinin aksamasına sebep olmuştur. Bu olumsuzluklar neticesinde, tanelerde yeterince nişasta birikiminin olmadığı, böylece tanelerin cilız kaldığı tahmin edilmektedir. Bindane ağırlı̆̆ının, hem verim hem de kalite komponenti olarak önemli bir yere sahip olduğu rapor edilmiştir (Ünal, 2002). Değişik iklim koşullarında farklı araştırıcılarca farklı genotipler kullanılarak yürütülen araştırmalarda, bindane ağıllıklarının; 25,75-55,9 g arasında değiștiği bildirilmiştir (Sözen ve Yağdı, 2005). Araştırmadan elde edilen sonuçlar; Aktaş ve İkincikarakaya (2019)'nın sonuçları ile uyumlu, Bayhan ve ark., (2019) sonuçlarının üstünde, Olgun ve ark., (2019) sonuçlarının altında değerler aldığı tespit edilmiştir.

Tablo 5. Ekmeklik buğday çeşitlerinin agronomik özelliklerine ait ortalamalar ve çoklu karşılaş̧tırma testi sonuçları

\begin{tabular}{|c|c|c|c|c|c|c|c|c|c|}
\hline \multirow[t]{2}{*}{ Çeşitler } & \multicolumn{3}{|c|}{ Bitki Boyu (cm) } & \multicolumn{3}{|c|}{ Hektolitre Ağırlığı (kg/hL) } & \multicolumn{3}{|c|}{ Bindane Ağırlığı (gr) } \\
\hline & 2018 & 2019 & Ortalama & 2018 & 2019 & Ortalama & 2018 & 2019 & Ortalama \\
\hline Tosunbey & $103.33 \mathrm{~d}-\mathrm{f}$ & $106.11 \mathrm{ab}$ & $104.72 \mathrm{ab}$ & $78.00 \mathrm{~b}-\mathrm{e}$ & $75.07 \mathrm{~b}-\mathrm{e}$ & $76.53 \mathrm{~b}-\mathrm{f}$ & 35.891 & $32.40 \mathrm{c}-\mathrm{e}$ & $34.15 \mathrm{f}-\mathrm{j}$ \\
\hline Bayraktar 2000 & $92.33 \mathrm{~g}$ & $97.44 \mathrm{~b}-\mathrm{f}$ & $94.89 \mathrm{fg}$ & $77.20 \mathrm{c}-\mathrm{g}$ & 74.95 b-e & $76.07 \mathrm{~b}-\mathrm{g}$ & $37.35 \mathrm{~g}-1$ & $29.60 \mathrm{f}-\mathrm{h}$ & $33.47 \mathrm{~h}-\mathrm{k}$ \\
\hline Gönen-98 & $100.00 \mathrm{f}$ & $94.26 \mathrm{c}-\mathrm{g}$ & $97.13 \mathrm{~d}-\mathrm{g}$ & $77.87 \mathrm{~b}-\mathrm{f}$ & 74.77 b-e & $76.32 \mathrm{~b}-\mathrm{g}$ & $41.47 \mathrm{~b}-\mathrm{f}$ & $27.73 \mathrm{~h}-\mathrm{j}$ & $34.60 \mathrm{e}-1$ \\
\hline Dicle 21 & $94.00 \mathrm{~g}$ & $82.66 \mathrm{~h} 1$ & $88.33 \mathrm{~h} 1$ & $76.80 \mathrm{e}-\mathrm{h}$ & $72.63 \mathrm{~d}-\mathrm{f}$ & $74.72 \mathrm{f}-\mathrm{h}$ & $41.32 \mathrm{~b}-\mathrm{f}$ & $30.40 \mathrm{~d}-\mathrm{g}$ & $35.86 \mathrm{c}-\mathrm{g}$ \\
\hline Karacadağ-98 & $85.00 \mathrm{~h}$ & 80.141 & $82.57 \mathrm{j}$ & 75.201 & 71.33 ef & $73.27 \mathrm{~h}$ & 36.371 & $26.00 \mathrm{j}-1$ & $31.19 \mathrm{~lm}$ \\
\hline & $103.67 \mathrm{~d}-\mathrm{f}$ & $101.52 \mathrm{a}-\mathrm{c}$ & $102.59 \mathrm{~b}-\mathrm{d}$ & $77.87 \mathrm{~b}-\mathrm{f}$ & $78.40 \mathrm{ab}$ & $78.13 \mathrm{~b}$ & 36.391 & $25.07 \mathrm{kl}$ & $30.73 \mathrm{~m}$ \\
\hline Pehliv & $95.00 \mathrm{~g}$ & $99.92 \mathrm{a}-\mathrm{d}$ & $97.46 \mathrm{~d}-\mathrm{g}$ & $77.60 \mathrm{c}-\mathrm{f}$ & $76.80 \mathrm{~b}-\mathrm{d}$ & $77.20 \mathrm{~b}-\mathrm{e}$ & $38.17 \mathrm{f}-1$ & $28.27 \mathrm{~g}-\mathrm{j}$ & $33.22 \mathrm{~h}-1$ \\
\hline 2001 & $94.67 \mathrm{~g}$ & $101.55 \mathrm{a}-\mathrm{c}$ & $98.11 \mathrm{~d}-\mathrm{g}$ & $76.00 \mathrm{~g}-1$ & $75.07 \mathrm{~b}-\mathrm{e}$ & $75.53 \mathrm{c}-\mathrm{h}$ & $41.03 \mathrm{~b}-\mathrm{f}$ & $28.80 \mathrm{~g}-1$ & $34.91 \mathrm{e}-1$ \\
\hline & $110.00 \mathrm{a}$ & 108.7 & 109. & 5.60 & 76.2 & & $37.03 \mathrm{~h} 1$ & 26.9 & $\mathrm{k}-\mathrm{m}$ \\
\hline & $106.00 \mathrm{~b}-\mathrm{d}$ & 90.00 & 98.00 & 76.80 & 71.3 & $74 .(1$ & $41.61 \mathrm{~b}-\mathrm{e}$ & 29.73 & d-g \\
\hline & $100.00 \mathrm{f}$ & $93.63 \mathrm{c}-\mathrm{g}$ & $96.81 \mathrm{e}-\mathrm{g}$ & $77.47 \mathrm{c}-\mathrm{f}$ & $75.97 \mathrm{~b}-\mathrm{e}$ & $76 .{ }^{\circ}$ & $40.81 \mathrm{c}-\mathrm{f}$ & $31.73 \mathrm{c}-\mathrm{f}$ & $36.27 \mathrm{c}-\mathrm{f}$ \\
\hline & $101.67 \mathrm{ef}$ & $95.07 \mathrm{c}-\mathrm{f}$ & $98.37 \mathrm{c}-\mathrm{g}$ & $79.73 \mathrm{a}$ & $75.49 \mathrm{~b}-\mathrm{e}$ & & $40.48 \mathrm{c}-\mathrm{g}$ & $32.80 \mathrm{~b}-\mathrm{e}$ & $54 \mathrm{c}-\mathrm{e}$ \\
\hline & 108.67 & 99.00 & 103.8 & 79.87 & 82.1 & & 38.3 & 30.2 & $3 \mathrm{f}-1$ \\
\hline & $8.00 \mathrm{a}-\mathrm{c}$ & $93.37 \mathrm{c}-\mathrm{h}$ & $100.68 \mathrm{~b}-\mathrm{e}$ & $76.93 \mathrm{~d}-\mathrm{g}$ & 74.6 & & $39.03 \mathrm{c}-1$ & $29.20 \mathrm{f}-1$ & $1 \mathrm{~g}-\mathrm{j}$ \\
\hline Kaşifbey & $101.67 \mathrm{ef}$ & $90.03 \mathrm{~d}-1$ & $95.85 \mathrm{e}-\mathrm{g}$ & $78.27 \mathrm{bc}$ & $73.33 c-f$ & $75.80 \mathrm{~b}-\mathrm{g}$ & $42.29 \mathrm{a}-\mathrm{c}$ & $28.13 \mathrm{~g}-\mathrm{j}$ & $35.21 \mathrm{~d}-\mathrm{h}$ \\
\hline & & 87.66 & & 700 & 69.7 & & $45.08 \mathrm{a}$ & & \\
\hline & $3.33 \mathrm{~d}-\mathrm{f}$ & 88 & & .00 & 74. & & $39.09 \mathrm{c}-1$ & & $b-d$ \\
\hline Cem & $104.67 \mathrm{c}-\mathrm{e}$ & $92.33 \mathrm{c}-\mathrm{h}$ & $98.50 \mathrm{c}-\mathrm{g}$ & $76.13 \mathrm{~g}-1$ & 74.50 b-e & $75.32 \mathrm{~d}-\mathrm{h}$ & $38.75 \mathrm{~d}-1$ & $33.07 \mathrm{bc}$ & $35.91 \mathrm{c}-\mathrm{g}$ \\
\hline & 101.00 ef & $96.85 \mathrm{~b}-\mathrm{f}$ & $98.93 \mathrm{c}-\mathrm{f}$ & $78.13 \mathrm{~b}-\mathrm{d}$ & $76.33 \mathrm{~b}-\mathrm{d}$ & $77.23 \mathrm{~b}-\mathrm{e}$ & $42.29 \mathrm{a}-\mathrm{c}$ & $33.60 \mathrm{bc}$ & $37.95 \mathrm{bc}$ \\
\hline & & & & & & & $a-d$ & & \\
\hline & $94.67 \mathrm{~g}$ & 95.96 & & 78.13 & 77.4 & & $44.37 \mathrm{ab}$ & 37.0 & $40.72 \mathrm{a}$ \\
\hline & $96.00 \mathrm{~g}$ & $90.41 \mathrm{~d}-1$ & $93.20 \mathrm{gh}$ & $76.67 \mathrm{f}-\mathrm{h}$ & $72.73 \mathrm{~d}-\mathrm{f}$ & $74.70 \mathrm{f}-\mathrm{h}$ & $40.00 \mathrm{c}-\mathrm{h}$ & $32.93 \mathrm{~b}-\mathrm{d}$ & $36.47 \mathrm{c}-\mathrm{e}$ \\
\hline & $94.67 \mathrm{~g}$ & & & 76.93 & $75.20 \mathrm{~b}-\mathrm{e}$ & & $38.21 \mathrm{e}-1$ & $27.87 \mathrm{~g}-\mathrm{j}$ & 33.04 1-1 \\
\hline Tekin & 88.33 & & & 78.00 & & & $42.39 \mathrm{a}-\mathrm{c}$ & & $35.26 \mathrm{~d}-\mathrm{h}$ \\
\hline Dariel & $.67 \mathrm{~h}$ & $83.56 \mathrm{~g}_{-1}$ & & $79.07 \mathrm{ab}$ & 71.50 ef & $75.28 \mathrm{~d}-\mathrm{h}$ & $40.61 \mathrm{c}-\mathrm{g}$ & 23.731 & $32.17 \mathrm{j}-\mathrm{m}$ \\
\hline Ortalama & $99.17 \mathrm{a}$ & $93.96 \mathrm{~b}$ & 96.57 & $77.53 \mathrm{a}$ & $74.97 \mathrm{~b}$ & 76.25 & $40.02 \mathrm{a}$ & $30.19 \mathrm{~b}$ & 35.11 \\
\hline $\mathrm{CV}$ & 2.27 & 7.04 & 5.12 & 0.98 & 3.84 & 2.75 & 5.18 & 5.34 & 5.29 \\
\hline LSD & $3.67 * *$ & $10.87 * *$ & $5.64 * *$ & $1.25^{* *}$ & $4.72 * *$ & $1.39 * *$ & $3.40 * *$ & $2.63 * *$ & $2.11 * *$ \\
\hline Ortalama LSD & & $3.90 *$ & & & $0.91 * *$ & & & $2.16^{* *}$ & \\
\hline
\end{tabular}


Farklı harfler ile gösterilen ortalamalar arasındaki fark p $<0.05$ düzeyinde önemlidir, C.V:Varyasyon Katsayısı, LSD: En kü̧̈ük anlamlı fark, Ö:D: Önemli değil.

\subsection{Yaş Gluten (YG, \%)}

Denemenin her iki yılı tüm ekmeklik buğday çeşitlerinin ortalama yaş gluten oranları; \% 30.68 (Adana-99) ile \% 41.33 (Dicle 21) arasında değiştiği belirlenmiştir. Denemenin her iki yıl yaş gluten oranları ortalaması \% 35.29 olup, Gönen-98, Dicle 21, Karacadağ98, Pehlivan, Sönmez 2001, Altay-2000, Cemre, Aldane, Gökkan, Yüreğir-89, Ceyhan-99, Tekin ve Dariel ekmeklik buğday çeşitlerinin bu ortalamanın üstünde değerler aldığı tespit edilmiştir (Tablo 6). Araştırmanın ilk yılına göre ikinci yılındaki yoğun yağışlar ve düşük seyreden sıcaklıklar, verim ve verim unsurlarında olduğu gibi yaş gluten oranlarını da düşürmüştür. Ekmeklik unlarda gluten proteinleri, hamurun kabarması ve elastikiyeti açısından önemli bileşenlerdendir (Schofield, 1994). Buğday protein oranın büyük bir kısmını glutenin yapısında olan gliadin ve glutenin proteinleri oluşturmaktadır. Kaliteli ekmeklik buğday ununun yaş gluten oranının \% 28'in üstünde olması gerektiği bildirilmiş̧tir (Erekul ve ark., 2005). Olumsuz iklim koşullarına rağmen, araştırmamızın her iki yılında da çeşitlerin tamamının ekmeklik un yapımında kullanılabilecek yaş gluten oranlarına sahip olduğu belirlenmiştir. Araştırmadan elde edilen sonuçlar, Koç ve Akgün (2019) ve Egesel ve ark., (2009)'nın sonuçlarının üstünde, Olgun ve ark., (2019) sonuçlarının altında değerler aldığı tespit edilmiştir.

\subsection{Kuru Gluten (KG, \%)}

Araştırmanın 2018 ve 2019 yılları tüm ekmeklik buğday çeşitlerinin ortalama kuru gluten oranları; \% 10.80 (PANDA `S) ile \% 15.87 (Pehlivan) arasında değiştiği belirlenmiştir. Denemede ki iki yılın kuru gluten oranları ortalaması; \% 12.66 olup, Tosunbey, Gönen-98, Dicle 21, Karacadağ-98, Pehlivan, Altay-2000, Nurkent, Pamukova-97, Cemre Aldane, Gökkan ve Dariel çeşitleri bu ortalamanın üstünde değerler aldığı saptanmıştır (Tablo 6). Kalite özelliklerinin çoğunda olduğu gibi kuru gluten değerlerinin iklim, toprak ve çeşide göre farklı değerler aldığı belirlenmiştir. Araştırmadan elde edilen sonuçlar; Menderis ve ark., (2008) ve Aydoğan ve ark., (2007)'nın sonuçlarının üstünde değerler aldığı tespit edilmiştir.

\subsection{Sedimentasyon $(\mathrm{S}, \mathrm{ml})$}

Çalışmanın her iki yılındaki tüm çeşitlerin ortalama sedimentasyon değerleri; 26.00 (İkizce-96) ile 40.67 (Dariel ve Cemre) ml arasında değiştiği saptanmıştır. Araştırmadaki iki yılın sedimentasyon ortalaması; $33.50 \mathrm{ml}$ olup, Gerek 79, Bezostaja 1, Cemre, Aldane, Gökkan, Yüreğir-89, Tekin ve Dariel ekmeklik buğday çeşitlerinin bu ortalamanın üstünde değerler aldığı tespit edilmiştir (Tablo 6). Çalışmanın yürütüldüğü yıllardaki farklı iklim koşulları ve çeşit özelliklerinden dolayı, sedimentasyon miktarlarının değişim gösterdiği tespit edilmiştir. Sedimentasyon miktarının, gluten kalite seviyesini belirleyen en önemli göstergelerden biri olduğu rapor edilmiştir (Zeleny ve ark., 1960). Sedimentasyon değeri, 25-36 ml arasında olanlar iyi, 36 ml'den yüksek olanların çok iyi gluten kalitesine sahip oldukları bildirilmiştir (Elgün ve ark., 2002). Bu veriler 1şığında, bütün buğday genotiplerinin sedimentasyon miktarlarının iyi düzeyde, bazılarının ise çok iyi düzeyde oldukları belirlenmiştir. Araştırmadan elde edilen sonuçlar, Koç ve Akgün (2019) ve Egesel ve ark., (2009)'nın sonuçları ile uyumlu, Olgun ve ark., (2019)'nın sonuçlarının altında değerler aldığı tespit edilmiştir. 
Tablo 6. Ekmeklik buğday genotiplerinin gluten ve sedimentasyon analizlerine ait ortalamalar ve çoklu karşılaştırma testi sonuçları

\begin{tabular}{|c|c|c|c|c|c|c|c|c|c|}
\hline \multirow[t]{2}{*}{ Çeşitler } & \multicolumn{3}{|c|}{ Yaş gluten $(\%)$} & \multicolumn{3}{|c|}{ Kuru gluten $(\%)$} & \multicolumn{3}{|c|}{ Sedimentasyon (ml) } \\
\hline & 2018 & 2019 & Ortalama & 2018 & 2019 & Ortalama & 2018 & 2019 & Ortalama \\
\hline Tosunbey & $38.03 \mathrm{a}-\mathrm{f}$ & $31.37 \mathrm{~d}-\mathrm{g}$ & $34.70 \mathrm{~d}-1$ & $13.63 \mathrm{~b}-\mathrm{g}$ & $11.83 \mathrm{c}-\mathrm{g}$ & $12.73 \mathrm{~b}-\mathrm{f}$ & $39.67 \mathrm{~b}-\mathrm{f}$ & $36.33 \mathrm{a}$ & $38.00 \mathrm{ab}$ \\
\hline Bayraktar 2000 & $36.20 \mathrm{c}-\mathrm{f}$ & $31.60 \mathrm{~d}-\mathrm{g}$ & $33.90 e-j$ & $12.67 \mathrm{~d}-\mathrm{g}$ & $11.63 \mathrm{c}-\mathrm{g}$ & $12.15 \mathrm{~d}-\mathrm{g}$ & $35.33 \mathrm{e}-1$ & $31.00 \mathrm{~d}-\mathrm{g}$ & $33.17 \mathrm{~d}-\mathrm{h}$ \\
\hline Gönen-98 & $40.37 \mathrm{a}-\mathrm{d}$ & $31.83 \mathrm{~d}-\mathrm{g}$ & $36.10 \mathrm{c}-\mathrm{g}$ & $14.50 \mathrm{a}-\mathrm{e}$ & $11.38 \mathrm{c}-\mathrm{g}$ & $12.94 \mathrm{~b}-\mathrm{e}$ & $36.67 \mathrm{c}-\mathrm{h}$ & $28.33 \mathrm{f}-\mathrm{j}$ & $32.50 \mathrm{f}-1$ \\
\hline Dicle 21 & $43.47 \mathrm{a}$ & $39.18 \mathrm{a}$ & $41.33 \mathrm{a}$ & $15.50 \mathrm{ab}$ & $12.93 \mathrm{~b}-\mathrm{d}$ & $14.22 \mathrm{~b}$ & $35.33 \mathrm{e}-1$ & $30.00 \mathrm{~d}-\mathrm{h}$ & $32.67 \mathrm{e}-\mathrm{h}$ \\
\hline Karacadağ-98 & $43.10 \mathrm{a}$ & $31.67 \mathrm{~d}-\mathrm{g}$ & $37.38 \mathrm{~b}-\mathrm{e}$ & $14.53 \mathrm{a}-\mathrm{d}$ & $10.93 \mathrm{~d}-\mathrm{g}$ & $12.73 b-f$ & $30.67 \mathrm{~h} 1$ & $26.001-\mathrm{k}$ & $28.33 \mathrm{ij}$ \\
\hline Gerek 79 & $34.30 \mathrm{~d}-\mathrm{f}$ & $31.55 \mathrm{~d}-\mathrm{g}$ & $32.93 \mathrm{~g}-\mathrm{j}$ & $12.23 \mathrm{fg}$ & $11.50 \mathrm{c}-\mathrm{g}$ & $11.87 \mathrm{~d}-\mathrm{g}$ & $43.67 \mathrm{a}-\mathrm{c}$ & $30.00 \mathrm{~d}-\mathrm{h}$ & 36.83 a-e \\
\hline Pehlivan & $41.67 \mathrm{a}-\mathrm{c}$ & $38.40 \mathrm{ab}$ & $40.03 \mathrm{ab}$ & $16.23 \mathrm{a}$ & $15.50 \mathrm{a}$ & $15.87 \mathrm{a}$ & $31.33 \mathrm{~g}-1$ & $30.00 \mathrm{~d}-\mathrm{h}$ & $30.67 \mathrm{~g}-1$ \\
\hline Sönmez 2001 & $38.37 \mathrm{a}-\mathrm{f}$ & $32.50 \mathrm{~d}-\mathrm{f}$ & $35.43 \mathrm{c}-\mathrm{f}$ & $13.80 \mathrm{~b}-\mathrm{g}$ & $11.37 \mathrm{c}-\mathrm{g}$ & $12.58 \mathrm{c}-\mathrm{f}$ & $35.33 \mathrm{e}-1$ & $30.00 \mathrm{~d}-\mathrm{h}$ & $32.67 \mathrm{e}-\mathrm{h}$ \\
\hline İkizce- & $3.03 \mathrm{a}-\mathrm{f}$ & $31.27 \mathrm{~d}-\mathrm{g}$ & $34.65 \mathrm{~d}-1$ & $13.33 \mathrm{c}-\mathrm{g}$ & $10.57 \mathrm{e}-\mathrm{g}$ & & 28.001 & & \\
\hline Altay & $38.37 \mathrm{a}-\mathrm{f}$ & $33.67 \mathrm{c}-\mathrm{f}$ & 36.0 & $13.17 \mathrm{c}-\mathrm{g}$ & 12.9 & & $32.33 \mathrm{f}-1$ & & \\
\hline Nurke & $36.63 \mathrm{~b}-\mathrm{f}$ & $33.49 \mathrm{c}-\mathrm{f}$ & $35.06 \mathrm{~d}-\mathrm{h}$ & $12.77 \mathrm{~d}-\mathrm{g}$ & $13.33 \mathrm{a}-\mathrm{c}$ & & $36.00 \mathrm{~d}-\mathrm{h}$ & 30.33 & $33.17 \mathrm{~d}-\mathrm{h}$ \\
\hline Pamukova-97 & 33.57 ef & $30.26 \mathrm{e}-\mathrm{g}$ & $31.91 \mathrm{~h}-\mathrm{j}$ & $12.37 \mathrm{e}-\mathrm{g}$ & $13.00 \mathrm{~b}-\mathrm{d}$ & & $34.33 \mathrm{e}-1$ & & $32.33 \mathrm{f}-1$ \\
\hline Bezost & $36.70 \mathrm{~b}-\mathrm{f}$ & & 34. & $13.00 \mathrm{c}-\mathrm{g}$ & $c-g$ & & $43.33 \mathrm{a}-\mathrm{d}$ & & $3 a-c$ \\
\hline Golia & $.83 \mathrm{f}$ & & $31.2^{\prime}$ & $12.07 \mathrm{fg}$ & $10.40 \mathrm{fg}$ & & $32.00 \mathrm{~g}-1$ & & \\
\hline Kaşifbey & $35.07 \mathrm{~d}-\mathrm{f}$ & $31.69 \mathrm{~d}-\mathrm{g}$ & $33.38 \mathrm{f}-\mathrm{j}$ & $12.37 \mathrm{e}-\mathrm{g}$ & $12.77 \mathrm{~b}-\mathrm{e}$ & $12.57 \mathrm{c}-\mathrm{f}$ & $37.00 \mathrm{c}-\mathrm{h}$ & $26.67 \mathrm{~h}-\mathrm{k}$ & $31.83 \mathrm{f}-1$ \\
\hline & $.03 \mathrm{f}$ & & $30.68 \mathrm{j}$ & $12.70 \mathrm{~d}-\mathrm{g}$ & $10.33 \mathrm{~g}$ & & $41.67 \mathrm{a}-\mathrm{e}$ & 24. & $33.17 \mathrm{~d}-\mathrm{h}$ \\
\hline PANDA & $.33 \mathrm{~d}-\mathrm{f}$ & 30.03 & 32.6 & $11.67 \mathrm{~g}$ & $9.93 \mathrm{~g}$ & & $36.67 \mathrm{c}-\mathrm{h}$ & $27.67 \mathrm{~g}-\mathrm{k}$ & $32.17 \mathrm{f}-1$ \\
\hline Cemre & $38.97 \mathrm{a}-\mathrm{f}$ & $32.25 \mathrm{~d}-\mathrm{g}$ & $35.61 \mathrm{c}-\mathrm{g}$ & $14.20 \mathrm{a}-\mathrm{f}$ & $11.43 \mathrm{c}-\mathrm{g}$ & $12.82 \mathrm{~b}-\mathrm{e}$ & $48.33 \mathrm{a}$ & $33.00 \mathrm{a}-\mathrm{d}$ & $40.67 \mathrm{a}$ \\
\hline Aldane & $37.27 \mathrm{a}-\mathrm{f}$ & $34.01 \mathrm{c}-\mathrm{e}$ & $35.64 \mathrm{c}-\mathrm{g}$ & $13.17 \mathrm{c}-\mathrm{g}$ & $14.37 \mathrm{ab}$ & $13.77 \mathrm{bc}$ & $38.33 \mathrm{c}-\mathrm{g}$ & $32.67 \mathrm{a}-\mathrm{d}$ & $35.50 \mathrm{~b}-\mathrm{f}$ \\
\hline Gökkan & $27 \mathrm{a}-\mathrm{f}$ & & & $13.77 \mathrm{~b}-\mathrm{g}$ & & & $38.00 \mathrm{c}-\mathrm{h}$ & & 0 a-d \\
\hline Yüre & $38.30 \mathrm{a}-\mathrm{f}$ & & $35.95 \mathrm{c}-\mathrm{g}$ & $13.10 \mathrm{c}-\mathrm{g}$ & 12.1 & & $37.33 \mathrm{c}-\mathrm{h}$ & 32.00 & $34.67 \mathrm{~b}-\mathrm{g}$ \\
\hline Kinac1-97 & $34.97 \mathrm{~d}-\mathrm{f}$ & $32.21 \mathrm{~d}-\mathrm{g}$ & $33.59 \mathrm{f}-\mathrm{j}$ & $12.00 \mathrm{~g}$ & $12.70 \mathrm{~b}-\mathrm{f}$ & $12.35 \mathrm{c}-\mathrm{g}$ & $32.67 \mathrm{f}-1$ & $29.33 \mathrm{~d}-1$ & $31.00 \mathrm{~g}-1$ \\
\hline Ceyhan 99 & $39.50 \mathrm{a}-\mathrm{e}$ & & $38.10 \mathrm{a}-\mathrm{d}$ & $12.97 \mathrm{c}-\mathrm{g}$ & $11.83 \mathrm{c}-\mathrm{g}$ & & $34.33 \mathrm{e}-1$ & & $33.17 \mathrm{~d}-\mathrm{h}$ \\
\hline Tekin & $5.23 c-f$ & & & $13.10 \mathrm{c}-\mathrm{g}$ & & & $39.67 \mathrm{~b}-\mathrm{f}$ & $27.67 \mathrm{~g}-\mathrm{k}$ & $33.67 \mathrm{c}-\mathrm{h}$ \\
\hline Darie & $.70 \mathrm{ab}$ & & 38.9 & $15.03 \mathrm{a}-\mathrm{c}$ & $11.67 \mathrm{c}-\mathrm{g}$ & $b-d$ & $46.00 \mathrm{ab}$ & $35.33 \mathrm{a}-\mathrm{c}$ & $40.67 \mathrm{a}$ \\
\hline Ort. & $37.65 \mathrm{a}$ & $32.92 \mathrm{~b}$ & 35.29 & $13.35 \mathrm{a}$ & $11.96 \mathrm{~b}$ & 12. & $36.96 \mathrm{a}$ & $30.04 \mathrm{~b}$ & 33.50 \\
\hline $\mathrm{CV}$ & 10.14 & 7.44 & 9.09 & 9.81 & 11.78 & 10.7 & 12.48 & 7.92 & 10.92 \\
\hline LSD $(0$ & $6.28 *$ & $4.02 * *$ & $3.66 * *$ & $2.15^{* *}$ & $2.31 * *$ & $1.54 * *$ & $7.55 * *$ & $3.89 * *$ & $4.17 * *$ \\
\hline Ortalama LSD & & $4.62 *$ & & & $1.32 *$ & & & $2.40 * *$ & \\
\hline
\end{tabular}

Farklı harfler ile gösterilen ortalamalar arasındaki fark p <0.05 düzeyinde önemlidir, C.V:Varyasyon KatsayıSı, LSD: En küçük anlamlı fark

\subsection{Protein Oranı (PO, \%)}

Denemenin tüm çeşitlerinin iki yıl ortalama protein oranları; \% 13.55 (Bayraktar 2000) ile \% 15.38 (Cemre) arasında değiştiği belirlenmiştir. Denemedeki iki yılın protein oranları ortalaması; \% 14.39 olup, Tosunbey, Dicle 21, Pehlivan, Pamukova-97, PANDA`S, Cemre, Aldane, Gökkan, Yüreğir-89, Kınac1-97, Ceyhan-99 ve Dariel ekmeklik buğday çeşitlerinin bu ortalamanın üstünde değerler aldığı tespit edilmiştir (Tablo 7). Denemenin ikinci yılına göre, daha sıcak ve kuru hava koşullarına sahip birinci yıldaki buğday genotiplerinin protein oranlarının daha yüksek olduğu belirlenmiştir. Denemenin ikinci yılındaki yoğun yağışların, sıcaklık değerlerinin düşük seyretmesine sebep olduğu saptanmıştır. Yapılan araştırmalarda, belirli derecelerde sıcaklık artışları, düşük nisbi nem ve su stresinin protein oranlarını artırdığı bildirilmiştir (Zhao ve ark, 2005). Çalışmadan elde edilen sonuçlar, Koç ve Akgün (2019) 'nün sonuçları ile uyumlu, Olgun ve ark., (2019) ve Egesel ve ark., (2009)'nın sonuçlarının üstünde değerler aldığı belirlenmiştir.

\subsection{Tane Verimi (TV, kg/da)}

Araştırmanın yapıldığı yıllarda bütün çeşitlerin ortalama tane verimleri; 363.78 (Dariel) ile 603.72 (Gökkan) kg/da arasında değiştiği tespit edilmiştir. Denemedeki iki yılın tane verim ortalaması; $479.26 \mathrm{~kg} / \mathrm{da}$ olup, Tosunbey, Sönmez 2001, Nurkent, Pamukova-97, Golia, Kaşifbey, Adana-99, PANDA`S, Cemre, Aldane, Gökkan, Yüreğir-89 çeşitlerinin bu ortalamanın üstünde değerler aldığı saptanmıştır (Tablo 7). Yıllar arasında tane verimlerinin değiştiği, araştırmanın ikinci yılında yaklaşık1000 mm yağan yağıştan dolayı, deneme alanında göllenmeler oluştuğu, bu durumun sağlıklı bir kök ve üst aksam (yaprak ve sap) gelişimini engellediği düşünülmektedir. Kök bölgesinin havasız kalması ile yer yer yapraklarda sararmalar gözlemlenmiş, sararan yapraklarda sağlıklı ve yeterli fotosentez gerçekleşmemiş bu zincirleme olayların neticesinde, bindane, hektolitre ve tane verimlerinde azalmalar olduğu tespit edilmiştir. İki yıllık sonuçlara göre stabil genotipler tespit edilmesine rağmen, genel anlamda ekmeklik buğday genotiplerinin, farklı iklim koşullarından olumsuz etkilendiği saptanmıştır. Tane verimlerinin iklim koşulları ve çeşide göre farklılık gösterdiği belirlenmiştir. Çalışmadan elde edilen sonuçlar, Aydoğan ve Soylu (2017)'nun verileri ile uyumlu, Koç ve Akgün (2019)'nun sonuçlarının altında, Bayhan ve ark., (2019) ve Aktaş ve İkincikarakaya (2019)'nın sonuçlarının üstünde değerler aldığı belirlenmiştir. 
European Journal of Science and Technology

Tablo 7. Ekmeklik buğday çeşitlerinin kalite ve verim özelliklerine ait ortalamalar ve çoklu karşılaştırma testi sonuçları

\begin{tabular}{|c|c|c|c|c|c|c|}
\hline \multirow[t]{2}{*}{ Çeşitler } & \multicolumn{3}{|c|}{ Protein oranı (\%) } & \multicolumn{3}{|c|}{ Tane verimi $(\mathrm{kg} / \mathrm{da})$} \\
\hline & 2018 & 2019 & Ortalama & 2018 & 2019 & Ortalama \\
\hline Bayraktar 2000 & $14.13 \mathrm{e}-\mathrm{g}$ & $12.97 \mathrm{n}$ & 13.551 & $468.78 \mathrm{e}-\mathrm{h}$ & $363.56 \mathrm{ij}$ & $416.17 \mathrm{~g}-\mathrm{j}$ \\
\hline Dicle 21 & $15.37 \mathrm{a}-\mathrm{c}$ & $13.53 \mathrm{k}-\mathrm{m}$ & $14.45 \mathrm{e}-\mathrm{g}$ & $477.00 \mathrm{~d}-\mathrm{h}$ & $356.56 \mathrm{ij}$ & $416.78 \mathrm{~g}-\mathrm{j}$ \\
\hline Karacadağ-98 & $14.47 \mathrm{~b}-\mathrm{g}$ & $13.60 \mathrm{kl}$ & $14.03 \mathrm{f}-1$ & $583.11 \mathrm{a}-\mathrm{e}$ & $299.44 \mathrm{k}$ & $441.28 \mathrm{f}-1$ \\
\hline Gerek 79 & $15.00 \mathrm{a}-\mathrm{f}$ & $13.70 \mathrm{j}-1$ & $14.35 \mathrm{e}-\mathrm{g}$ & $623.33 \mathrm{ab}$ & $293.00 \mathrm{k}$ & $458.17 \mathrm{e}-1$ \\
\hline İkizce-96 & $14.13 \mathrm{e}-\mathrm{g}$ & $13.10 \mathrm{mn}$ & 13.621 & $509.33 \mathrm{~b}-\mathrm{h}$ & $367.78 \mathrm{ij}$ & $438.56 \mathrm{f}-1$ \\
\hline Altay-2000 & $14.10 \mathrm{e}-\mathrm{g}$ & $13.43 \mathrm{~lm}$ & $13.77 \mathrm{~h} 1$ & $549.78 \mathrm{a}-\mathrm{g}$ & $385.33 \mathrm{~h}-\mathrm{j}$ & $467.56 \mathrm{~d}-1$ \\
\hline Nurkent & $14.57 \mathrm{~b}-\mathrm{g}$ & $14.20 \mathrm{f}-\mathrm{h}$ & $14.38 \mathrm{e}-\mathrm{g}$ & $558.33 \mathrm{a}-\mathrm{f}$ & $445.56 \mathrm{~d}-\mathrm{g}$ & $501.94 \mathrm{~b}-\mathrm{f}$ \\
\hline Pamukova-97 & $14.03 \mathrm{e}-\mathrm{g}$ & $15.07 \mathrm{a}-\mathrm{c}$ & $14.55 \mathrm{~d}-\mathrm{f}$ & $542.33 \mathrm{a}-\mathrm{g}$ & $597.33 \mathrm{a}$ & $569.83 \mathrm{ab}$ \\
\hline Bezostaja 1 & $14.23 \mathrm{~d}-\mathrm{g}$ & $13.731-1$ & $13.98 \mathrm{~g}-1$ & $551.78 \mathrm{a}-\mathrm{g}$ & $401.33 \mathrm{~g}-1$ & $476.56 \mathrm{c}-\mathrm{h}$ \\
\hline Cemre & $15.43 \mathrm{ab}$ & $15.33 \mathrm{a}$ & $15.38 \mathrm{a}$ & $420.00 \mathrm{gh}$ & $541.56 \mathrm{bc}$ & $480.78 \mathrm{c}-\mathrm{g}$ \\
\hline Aldane & $14.83 \mathrm{~b}-\mathrm{f}$ & $14.63 \mathrm{c}-\mathrm{f}$ & $14.73 \mathrm{~b}-\mathrm{e}$ & $436.67 \mathrm{f}-\mathrm{h}$ & $539.44 \mathrm{bc}$ & $488.06 \mathrm{c}-\mathrm{f}$ \\
\hline Gökkan & $15.03 \mathrm{a}-\mathrm{e}$ & $15.20 \mathrm{ab}$ & $15.12 \mathrm{a}-\mathrm{c}$ & $591.22 \mathrm{a}-\mathrm{e}$ & $616.22 \mathrm{a}$ & $603.72 \mathrm{a}$ \\
\hline Yüreğir-89 & $14.40 \mathrm{c}-\mathrm{g}$ & $14.87 \mathrm{~b}-\mathrm{d}$ & $14.63 \mathrm{c}-\mathrm{e}$ & 470.78 d-h & $568.61 \mathrm{ab}$ & $519.69 \mathrm{~b}-\mathrm{e}$ \\
\hline Kınac1-97 & $14.73 \mathrm{~b}-\mathrm{g}$ & $14.77 \mathrm{~b}-\mathrm{e}$ & $14.75 \mathrm{~b}-\mathrm{e}$ & $518.11 \mathrm{~b}-\mathrm{h}$ & $437.44 \mathrm{e}-\mathrm{g}$ & $477.78 \mathrm{c}-\mathrm{g}$ \\
\hline Ceyhan 99 & $15.03 \mathrm{a}-\mathrm{e}$ & $15.33 \mathrm{a}$ & $15.18 \mathrm{ab}$ & $506.00 \mathrm{~b}-\mathrm{h}$ & $379.61 \mathrm{~h}-\mathrm{j}$ & $442.81 \mathrm{f}-1$ \\
\hline Tekin & $14.67 \mathrm{~b}-\mathrm{g}$ & $14.07 \mathrm{~g}-\mathrm{j}$ & $14.37 \mathrm{e}-\mathrm{g}$ & 493.78 b-h & $302.89 \mathrm{k}$ & $398.33 \mathrm{ij}$ \\
\hline Dariel & $16.00 \mathrm{a}$ & $14.07 \mathrm{~g}-\mathrm{j}$ & $15.03 \mathrm{a}-\mathrm{d}$ & $385.22 \mathrm{~h}$ & $342.33 \mathrm{jk}$ & $363.78 \mathrm{j}$ \\
\hline Ort. & $14.64 \mathrm{a}$ & $14.13 \mathrm{~b}$ & 14.39 & $529.79 \mathrm{a}$ & $428.74 \mathrm{~b}$ & 479.26 \\
\hline $\mathrm{CV}$ & 4.24 & 1.91 & 3.26 & 15.59 & 7.02 & 12.97 \\
\hline LSD (0.05) & $1.02 * *$ & $0.44 * *$ & $0.53 * *$ & $135.61 *$ & $49.42 * *$ & $71.08 * *$ \\
\hline
\end{tabular}

Farklı harfler ile gösterilen ortalamalar arasındaki fark p <0.05 düzeyinde önemlidir. C.V:Varyasyon KatsayıSı. LSD: En küçük anlamlı fark

\section{9 Özellikler ve Çeşitler Arası Biplot Analizi}

Scatter biplot yöntemi ile yapılan analizde PC1 (1. ana bileşen); \% 31.62, PC2 (2. ana bileşen); \% 24.90 olmak üzere toplamda varyasyonun \% 56.52 olduğu belirlenmiştir. Grafiğin I. bölgesinde yer alan BA, HA, TV ve BB ile Grafiğin II. Bölgesinde yer alan S, PO, YG ve KG özelliklerini temsil eden vektörlerin arasındaki açıların 90 dereceden düşük ve aynı yönde yer almasından dolayı, bu özellikler arasında yüksek bir pozitif korelasyonun olduğu söylenebilir. Grafiğin negatif tarafinda özellik olmadığından dolayı, I ve II bölgedeki bütün özelliklerin birbiriyle orta ve yüksek pozitif korelasyon içerisinde olduğu saptanmıştır. Birbiriyle olumlu ilişkide olan özellikler ile bu özellikler bakımından en yüksek değerlere sahip olan ekmeklik buğday çeşitlerinin aynı bölgelerde yer aldıkları belirlenmiştir. Özellikleri temsil eden vektörlerin üzerinde olan genotiplerin o özellik bakımından öne çıktığı söylenebilir. Vektörlerin uç taraflarında yer alan genotiplerin hem stabil hem de yüksek değerlere sahip olduğu belirlenmiştir. Grafiğin I. bölgesinde yer alan, TV özelliği bakımından Pamukova-97, Kaşifbey, Adana-99, PANDA`S ve Gökkan ekmeklik buğday çeşitlerinin, BB boyu bakımından Kaşifbey, Adana-99 ve PANDA'S çeşitlerinin, BA ve HA bakımından Tosunbey, Nurkent, Bezostaja 1, Yüreğir-89 ve Kınac1-97 çeşitlerinin hem stabil hem de yüksek değerlere sahip olduğu tespit edilmiştir. Grafiğin II. bölgesinde yer alan, YG, KG, PO ve S özellikleri bakımından Dicle 21, Pehlivan, Cemre, Aldane, Ceyhan 99 ve Tekin ekmeklik buğday çeşitlerinin hem stabil hem de yüksek kalite özelliklerine sahip olduğu saptanmıştır. Özelliklerin olduğu I ve II bölgenin dışında kalan Bayraktar 2000, Gönen-98, Karacadağ-98, Sönmez 2001, İkizce-96, Altay-2000 ve Golia çeşitlerinin iki yıllık çalışmada stabil olmadıkları ve düşük performanslar gösterdikleri belirlenmiştir (Tablo 8). Ekmeklik buğday ile ilgili yapılan araştırmalarda tescil edilecek çeşitlerin; yüksek verimli, kaliteli, biyotik ve abiyotik stres koşullarına dayanıklı, bu özelliklerini değişik koşullarda ve farklı yıllarda fazla değiştirmeyen, stabil çeşitler olması gerektiği bildirilmiştir (Kün, 1996). 
Tablo 8. Özellikler ve Çeşitler Arasında ki Illişkiyi Gösteren Biplot Grafiği

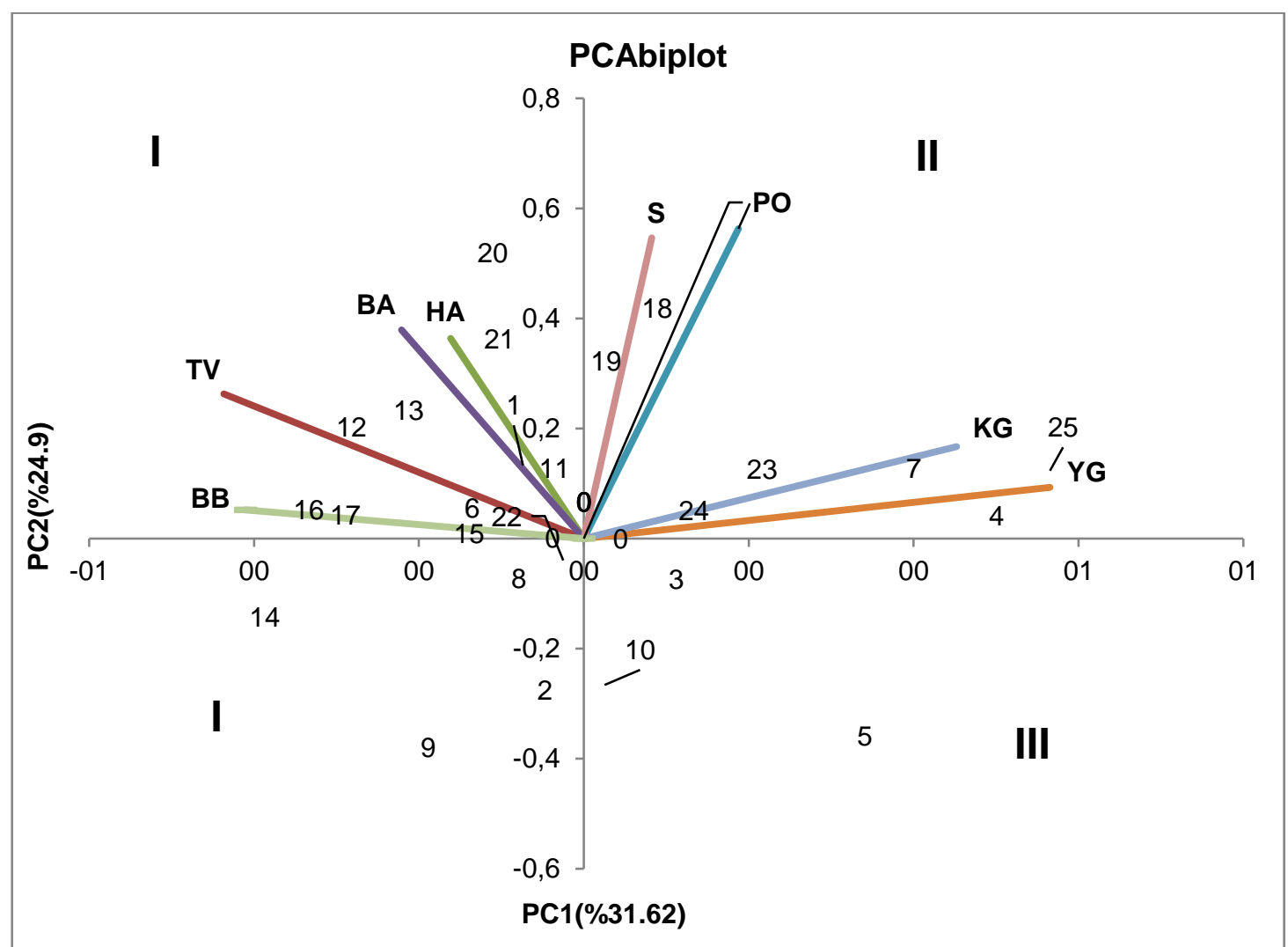

+ BB: Bitki Boyu (cm), HA: Hektolitre Ağırlığı (kg/hL), BA: Bindane Ağırlığı (gr), YG: Yaş Gluten (\%), KG: Kuru Gluten (\%), S: Sedimentasyon (ml), PO: Protein Oranı (\%), TV: Tane Verimi (kg/da), 1:Tosunbey, 2: Bayraktar 2000, 3: Gönen-98, 4: Dicle 21, 5: Karacadağ-98, 6: Gerek 79, 7: Pehlivan, 8:Sönmez 2001, 9: İkizce-96, 10: Altay-2000, 11: Nurkent, 12: Pamukova-97, 13: Bezostaja 1, 14: Golia, 15: Kaşifbey, 16: Adana-99, 17: PANDA`S, 18: Cemre, 19: Aldane, 20: Gökkan, 21: Yüreğir-89, 22: Kınac1-97, 23: Ceyhan 99, 24: Tekin, 25: Dariel

\section{Sonuç}

Bu araştırma, GAP koşullarında 2018 ve 2019 yıllarında 25 adet ekmeklik buğday çeşidinin tane verimi, verim unsurları ve kalite özelliklerini belirlemek amacıyla yürütülmüştür. Denemenin birinci yılına nazaran, ikinci yılda yaklaşık 1000 mm yağan yağış miktarı ve düşük seyreden sıcaklıklar, bitki gelişimini olumsuz etkilemiş bunun neticesinde hem tane verimleri hem de kalite özelliklerinde azalmalar tespit edilmiştir. Denemenin ikinci yılındaki yağışlardan dolayı, yer yer göllenmelerin oluşması, göllenmelerin kök bölgesini havasız bırakması, bitkinin topraktan yeterince su ve besin maddesi alamamasına dolayısıyla sağlıklı bir fotosentezin gerçekleşememesine neden olmuştur. Özellikler ve çeşitler arasındaki ilişkileri saptamak amacıyla biplot analizi yapılmıştır. Araştırmada incelenen özelliklerin birbiri ile orta ve yüksek düzeyde pozitif korelasyona sahip oldukları belirlenmiştir. Yıllar arasında iklim farklarına rağmen, tek ve çoklu özellik bakımından stabil ve iyi performans gösteren ekmeklik buğday çeşitleri belirlenmiştir. Denemeye alınan çoğu çeşidin kabul edilir sınırlarda kalite özelliklerine sahip oldukları saptanmıştır. Denemede ki Pamukova-97, Kaşifbey, Adana-99, PANDA 'S ve Gökkan çeşitlerinin stabil tane verimi ve kabul edilir sınırlarda kalite özelliklerine sahip oldukları belirlenmiştir. Bundan sonraki ekmeklik buğday 1slah çalışmalarında ekstrem koşullarda fizyolojik ölçümlerle çeşitlerin stres koşullarına tolerans düzeyleri belirlenerek, stabil çeşitlerin tescili ülke tarımına ve ekonomisine katkılar sunacaktır.

\section{Kaynakça}

Anonymous, (1990). Official methods of analysis of the AOAC, fifteenth edition Association Official Analytical Chemists, Arlington. Atlı, A. (1999). Buğday ve ürünleri kalitesi, Orta Anadolu'da hububat tarımının sorunlarl ve çözüm yolları sempozyumu, 8-11 Haziran, (s., 498-506). Konya, Türkiye

Aydoğan, S., Akçacık, G.A., Şahin, M., \& Kaya, Y. (2007). Ekmeklik buğday (t. aestivum L.) genotiplerinde verim ve bazı kalite özellikleri arasındaki ilişkiler, Tarla Bitkileri Merkez Araştırma Enstitüsü Dergisi, 3(2), 21-30.

Aydoğan, S., \& Soylu, S., (2017). Ekmeklik buğday çeşitlerinin verim ve verim öğeleri ile bazı kalite özelliklerinin belirlenmesi. Tarla Bitkileri Merkez Araştırma Enstitüsü Dergisi, 26 (1), 24-30.

Aktaş, B., \& İkincikarakaya, S.Ü. (2019). Ekmeklik buğday (Triticum aestivum L.) genotiplerinin verim ve verim unsurları ile glutenin ve gliadin bant desenlerinin belirlenmesi. Mediterranean Agricultural Sciences, 32(1), 85-93.

Anonim, (2019). Devlet Meteoroloji İşleri Genel Müdürlüğü, Şanlıurfa İl Müdürlüğü verileri (erişim tarihi: 14.04.2020).

Anonim, (2020a). Food and Agriculture Organization. www.faostat.org.(erişim tarihi: 01.02.2020) 
Anonim, (2020b). Bitkisel üretim verileri istatistikleri. Türkiye İstatistik Kurumu. www.tuik.gov.tr( erişim tarihi: 01.04.2020).

Bassett, L.M., Allan, R.E., \& Rubenthaler, G.L. (1989). Genotype x environment interactions on soft white winter quality. Journal of Agronomy, 81 (3), 955-960.

Bonfil, D.J., Karnieli, A., Raz, M., Mufradi, I., Asido, S., Egozi, H., Hoffman, A., \& Schmilovitch, Z. (2004). Decision support system for improving wheat grain quality in the Mediterranean area of Israel. Journal of Field Crops Research 89(4), 153-163.

Bayhan, M., Özkan, R., Albayrak, Ö., Yıldırım, M., \& Akıncı, C., (2019). Aşırı kurak sezonda ekmeklik buğday genotiplerinin performanslarının test edilmesi. 2. Uluslararası Mardin Artuklu Bilimsel Araştırmalar Kongresi, bildiriler kitabı, 23-25 Ağustos, (s., 162-169). Mardin, Türkiye.

Elgün, A., Türker, S., \& Bilgiçli, N. (2001). Tahıl ve ürünlerinde analitik kalite kontrolü, Selçuk Üniversitesi Ziraat Fakültesi Gıda Mühendisliği Bölümü Ders Notları, Konya Ticaret Borsası, Yayın No: 2, Konya, Türkiye.

Elgün, A., Ertugay, Z., Certel, M., \& Kotancılar, H.G. (2002). Tahıl ve ürünlerinde analitik kalite kontrolü ve laboratuvar uygulama kılavuzu (düzeltilmiş 3. Baskı). Atatürk Üniversitesi Yayın No: 867, 245s Erzurum, Türkiye.

Erekul, O., Oncan, F., Erekul, A., Yava, İ., Engün, B., \& Koca, Y.O. (2005). İleri ekmeklik buğday hatlarında verim ve bazı kalite özelliklerinin belirlenmesi. Türkiye VI. Tarla Bitkileri Kongresi. (s., 111-116). 5-9 Eylül, Antalya, Türkiye

Egesel, C.Ö., Kahraman, F., Tayyar, Ş., \& Baytekin, H. (2009). Ekmeklik buğdayda un kalite özellikleri ile dane veriminin karş1lıklı etkileşimleri ve uygun çeşit seçimi. Anadolu Tarım Bilimi Dergisi, 24(2), 76-83.

Kün, E., (1996). Tahıllar-I (Serin İklim Tahılları). Ankara Üniversitesi Ziraat Fakültesi Yayınları, Yayın No:1451, Ankara.

Koç, A., \& Akgün, İ. (2019). Sahil kuşağında ICARDA-CIMMYT ekmeklik buğday genotiplerinin verim ve bazı kalite özellikleri yönünden karşılaştırılması. Süleyman Demirel Üniversitesi Fen Bilimleri Enstitüsü Dergisi, 23 (1), 146-151.

Menderis, M., Atl, A., Köten, M., \& Kılıç, H. (2008). Gluten indeks değeri ve yaş gluten/protein oranı ile kalite değerlendirilmesi. Harran üniversitesi Ziraat Fakültesi Dergisi, 12(3), 57-64.

Olgun, M., Başçiftçi, Z.B., Arpacıoğlu, G:A., Katar, D., \& Aydın, D. (2019). Ekmeklik buğday (Triticum aestivum L.) çeşitlerinde kalite özelliklerinin belirlenmesi. Uluslararası Uygulamalı Biyoloji ve Çevre Bilimleri Dergisi, 1(2), 5-11.

Pena, R.J., Amaya, A., Rajaram, S., \& Mujeeb, A. (1990). Variation in quality characteristics with some spring 1B/1R translocation wheats, Journal of Cereal Science, 12 (3), 105-112.

Peterson, C.J., Graybosch, R.A., Shelton, D.R., \& Baenziger, P.S. (1998). Baking quality of hard winter wheat: response of cultivars to environment in the great plains. Kluwer Academic Publishers, Dordrecht, pp. 223-228.

Pfluger L.A., D'Ovidio, R., Margiotta, B., \& Pena, R. (2001). Characterisation of high- and low molecular weight glutenin subunits associated to the D genome of Aegilops tauschii in a collection of synthetic hexaploid wheats. International Journal of Plant Breeding Research, 103 (3), 1293-1301.

Smith, G.P., \& Gooding, M.J. (1999). Models of wheat grain quality considering climate cultivar and nitrogen effects. Journal of Agriculture Forest and Meteorology, 94 (2), 159 -170.

Schofield, J.D. (1994). Wheat proteins: structure and functionality in milling and bread making. London Congress, Chapman and Hall, (pp.,73-106), England.

Sözen, E., \& Yağdı, K. (2005). Bazı ileri makarnalık buğday hatlarının tarımsal özelikleri üzerine araştırmalar, Adnan Menderes Üniversitesi Ziraat Fakültesi Dergisi; 2(2), 51-57.

Ünal, S. (2002). Buğdayda kalitenin önemi ve belirlenmesinde kullanılan yöntemler. Hububat Ürünleri Teknolojisi Kongre ve Sergisi, 3-4 Ekim, (s., 25-37). Gaziantep, Türkiye.

Zeleny, L., Greenaway, W.T., Gurney, G.M., Fifield, C.C., \& Lebsock, K. (1960). Sedimentation value as an index of dough mixing characteristics in early generation wheat selections. Journal of Cereal Chemistry, 37 (4), 673-681.

Zhao, C.H., Liu, L., Wang, J., Huang, W., Song, X., \& Li, C. (2005). Predicting grain protein content of winter wheat using remote sensing data based on nitrogen status and water stress. International Journal of Applied Earth Observation and Geoinformation, 7 (2), 1-9. 